\title{
Perceived Coach Attitudes and Behaviors Scale: Development and Validation Study
}

\author{
Hanifi Üzüm ${ }^{1}$, Ünal Karlı ${ }^{1}$, Nuh Osman Yıldız ${ }^{1}$ \\ ${ }^{1}$ School of Physical Education and Sport, Abant Izzet Baysal University, Bolu, Turkey \\ Correspondence: Hanifi Uzum, School of Physical Education and Sport, Abant Izzet Baysal University, Bolu, Turkey.
}

Received: February 12, 2018

Accepted: February 20, 2018

Online Published: February 24, 2018

doi:10.11114/jets.v6i3.3018

URL: https://doi.org/10.11114/jets.v6i3.3018

\begin{abstract}
The purpose of the study was to develop a scale, which will serve to determine how attitudes and behaviors of the coaches are perceived by the athletes. The scale, named as "Perceived Coach Attitudes and Behaviors Scale" (PCABS) was developed through various processes including exploratory and confirmatory factor analysis. Following the literature review process in the beginning stage, focus group interviews were conducted. As a result of literature review process and focus group interviews an item pool of 61 items was formed, and after gathering the opinions and critics of experts in the area of language and sports science, the final form of the scale was constructed. The exploratory factor analysis (EFA) on 200 athletes revealed a construct comprised of 25 items and 3 sub-dimensions. Subsequently, confirmatory factor analysis (CFA) conducted on 266 athletes confirmed the structural validity of the scale composed of 24 items and 3 sub-dimensions. The first sub-dimension named "Characteristic Features ", with an internal consistency value of 0.88 , consisted of items $1,2,3,4,6,7,8,9,10,11,18,20$, and 23 . The second sub-dimension named "Knowledge and Skills Accumulation" consisted of items 13, 14, 15, 16, 17, 19, 21, 22, and 24 had an internal consistency value of 0.86 . The final sub-dimension named "Being Fair" consisted of 5th and 12th items with an internal consistency value of 0.56 . Items $1,2,3,4,6,7,8,9,10,18,20$ and 23 were reverse coded items of the scale.
\end{abstract}

As a conclusion, the analysis revealed that "Perceived Coach Attitudes and Behaviors Scale", with its three sub-dimensions and 24 items, is a structurally valid and reliable scale, can be used to identify the athletes' perceptions about their coaches.

Keywords: coach, fairness, sufficiency, perception

\section{Introduction}

Behaviors and attitudes performed by individuals are important determinant factors on people's perceptions they deal or communicate with in daily life. Behaviors of individuals might emerge as choices which came into existence because of their attitudes. Allport (1935) explained attitude as cognitive and affective circumstances which are directing individual's behaviors or exerting a dynamic influence in response to certain situations or objects as an outcome of their experiences and the events that they have gone through. Nowadays, it is observed that the number of studies regarding attitudes and behavior concepts -which are scientifically being subjects of researches in many fields from education to politics, commerce to industry-, is increasing day by day among the occupational groups such as management, marketing and sports. It is expected for the individuals belonging to a professional group to display equitable, just and human behaviors while practicing their profession. Sufficiency in a field of occupation is not only about having the knowledge and skills but also having accurate attitudes and behaviors concerning that field of profession (Dolaşır Tuncel and Büyüköztürk, 2009, p.159, 160). This situation applies to coaches too who are one of the essentials of athletic environment that is being seen as a common language around the whole world. Even though a coach has duties such as training the athletes or showing them how sportive skills done, transferring information to athletes after gathering from sports scientists, sports doctors and sports psychologists and combining and synthesizing them with his/her own existing information (Güven and Öncü, 2012, p.68), he/she also needs to be able to understand how his/her player feels in a training atmosphere during and after competition or in cases of victory and defeat and empathize with the athlete (Karakoç et al. 2011, p.322). When having a look at the tasks of a coach, it's not only training the athletes technically. At the same time, a coach needs to exhibit attitudes and behaviors that will provide an environment for also a psychological win against the opponents. Therefore, attitudes and behaviors shown by the coaches have an importance 
for constituting the notions such as the accomplishments of the athletes, team climate and communication within the organization (Smith et al. 1983, p.213).

In this context, it's being seen that the studies intended for coach attitudes and behaviors are increasing in the literature (Tharp and Gallimore, 1976; Smith et al., 1979; Chelladurai, 1984; Kenow and Williams, 1999; Teatro, 2014). When studies that were made on coach attitudes and behaviors are examined, it's pointed out that the majority of them are designed according to qualitative research methods. Hence this study what is aiming to develop a scale which is going to ensure measuring how attitudes and behaviors displayed by the coaches are being perceived by the athletes is considered to be important for theoretically defining those aspects, as for practically, creating a self-evaluation opportunity for coaches and sports managers. When previous works analyzed, the studies which were categorizing coach attitudes and behaviors in different magnitudes from past to present day and on different coach manners and behaviors such as coaches' sufficiency, fairness, ethic principals and behaviors are being seen. In a study made by Gilbert and Trudel (2004), coach attitudes and behaviors were summed in 4 dimensions as "the best implementations" which are being tried by the coach (leadership style, effectiveness, general relationships), "coach behavior" (attitudes, way of decision making, informing and perception), "characteristics of the coach" (age, gender and such demographic variables) and "career development of the coach" (education, athletics background, idealism and competency). In another study conducted by Gearity (2012) ethical and unethical behaviors of the coach were investigated. In a research by Tharp and Gallimore (1976), a basketball coach was observed in practice and competition environments for more than 30 hours. In the wake of observations, approximately 2300 codes were formed. These codes were grouped under 10 categories which are expressing coach behavior styles. In consequence of the study, coach behaviors during education such as scolding, rudeness, harsh communication and encouragement were resulted to be the dominant ones. When all these studies and literature are considered, in this work as well, items and sub-dimensions of the mentioned scale which will be developed were created in the light of literature and previous researches, and it was predicted that attitudes and behavior patterns which were found in studies can be gathered in 4 dimensions as coach's character, sufficiency, communication with the athletes and fairness. In this study which was conducted based on these four sub-dimensions, it was intended to bring a valid and reliable quantitative measurement tool into the literature to measure how displayed attitudes and behaviors of people who are coaching in team sports and individual sports are being perceived by the athletes.

\section{Method}

\subsection{Participants and Procedures}

\section{Exploratory Factor Analysis Study Group}

For EFA, data collected from a sample of 200 athletes, consisted of 95 females and 105 males, who were contestant athletes from 16 different sports branches which were categorized as team sports and individual sports.

\section{Confirmatory Factor Analysis Study Group}

In CFA stage, the sample group was composed of contestant athletes ( $\mathrm{n}=266 ; 128$ female and 138 male) from16 different team and individual sports branches. Data was collected with face-to-face interview method. Participants' average age is $20.69 \pm 4.99$.

\subsection{Instrument and Data Collection Tool}

For the creation of item pool of "Perceived Coach Attitudes and Behaviors Scale", initially, the relevant national and international literature were thoroughly reviewed (Teatro (2014), Güven and Öncü (2012), Gearity (2012), Dolaşır Tuncel and Büyüköztürk (2009), Gilbert and Trudel (2004), Tharp and Gallimore (1976). Afterwards the literature review process, semi-structured interviews were prepared and conducted with athletes who attended the tournaments organized by the sports federations in 2017. As a result of the interviews, coach's sufficiency, communication with the athletes, characteristics of coach and fairness emerged as important main themes.

Based on the process an item pool consisted of 61 questions were grouped under 4 sub-dimensions. For expert validity, the items were evaluated and reviewed by three academicians working in the field of Physical Education and Sport science. Following the necessary editing made by the experts, the scale was inspected by two Turkish linguists and it was finalized after required and suggested corrections. The first part of the scale was composed of demographic questions and the second part was consisted of 61 items reflecting perceived coach behaviors and attitudes. In the item evaluation 5-point likert type scale was used (Never=1 to Always=5).

\subsection{Data Analysis}

Exploratory factor analysis (EFA) and confirmatory factor analysis (CFA) were used for the validity analysis of scale. In the EFA, principal components analysis method was employed with varimax axis rotation test. Kaiser-Meyer-Olkin 
(KMO) measure of sampling adequacy and Bartlett's test of Sphericity were conducted for measuring the applicability of EFA. Eigen Value and Scree Plot tests were performed for determining the significant components and deciding factorial structure of the scale.

In CFA, goodness of fit, standard loads, R2 values and t-values were checked. For testing the reliability of sub-dimensions Cronbach's Alpha internal consistency test was conducted. Finally, Pearson Correlation analysis was used to see relationships of the sub-dimensions with each other which were procured from the scale.

\section{Results}

Initially, preliminary tests such as KMO and Bartlett's Sphericity test results checked to see the adequacy of sample and suitability of the sample for conducting EFA. KMO and Bartlett's test results are reported in Table 1.

Table 1. KMO and Bartlett's Sphericity Test Results

\begin{tabular}{lcc}
\hline \multicolumn{2}{c}{ Kaiser-Meyer-Olkin Measure of Sampling Adequacy } & $\mathbf{0 . 8 8}$ \\
\hline \multirow{3}{*}{ Bartlett's Sphericity Test } & Approximate Chi-Square & 5772.149 \\
& Degrees of Freedom & 1653 \\
& Significance & 0.000 \\
\hline
\end{tabular}

When Table 1 is analyzed, it was noted that the scale's KMO measure of sampling adequacy value is 0.88 and significance value of Bartlett's Sphericity Test is significant, $\mathrm{P}<0.01$.

Table 2. Eigenvalues and The Explained Variances

\section{Total Variance Explained}

\begin{tabular}{ccccccc} 
& \multicolumn{3}{c}{ Initial Eigenvalues } & \multicolumn{3}{c}{ Loads After Rotations } \\
\cline { 2 - 7 } Component & Total & \% of Variance & Cumulative $\%$ & Total \% of Variance $\begin{array}{c}\text { Cumulative } \\
\%\end{array}$ \\
\hline $\mathbf{1}$ & 16.440 & 28.345 & 15.653 & 8.005 & 32.019 & 22.206 \\
$\mathbf{2}$ & 3.212 & 5.537 & 31.169 & 2.311 & 9.245 & 40.655 \\
$\mathbf{3}$ & 2.478 & 4.272 & 37.207 & 1.623 & 6.493 & 47.757 \\
$\mathbf{4}$ & 1.849 & 3.188 & 41.343 & & & \\
\hline
\end{tabular}

After examining Table 2, it is observed that 25 of the analyzed items are grouped under three factors which have eigenvalues higher than 1 . These three obtained factors are explaining approximately $47.757 \%$ of the total variance.

Scree plot analysis results, which show that in how many dimensions the items can be summed according to the eigenvalues, are presented at Figure 1. When the graphic is investigated, it's seen that the optimum factor number at vertical axis that witnesses rapid declines with high momentum is three and the contributions that were brought by additional factors subsequent to three are close to each other.

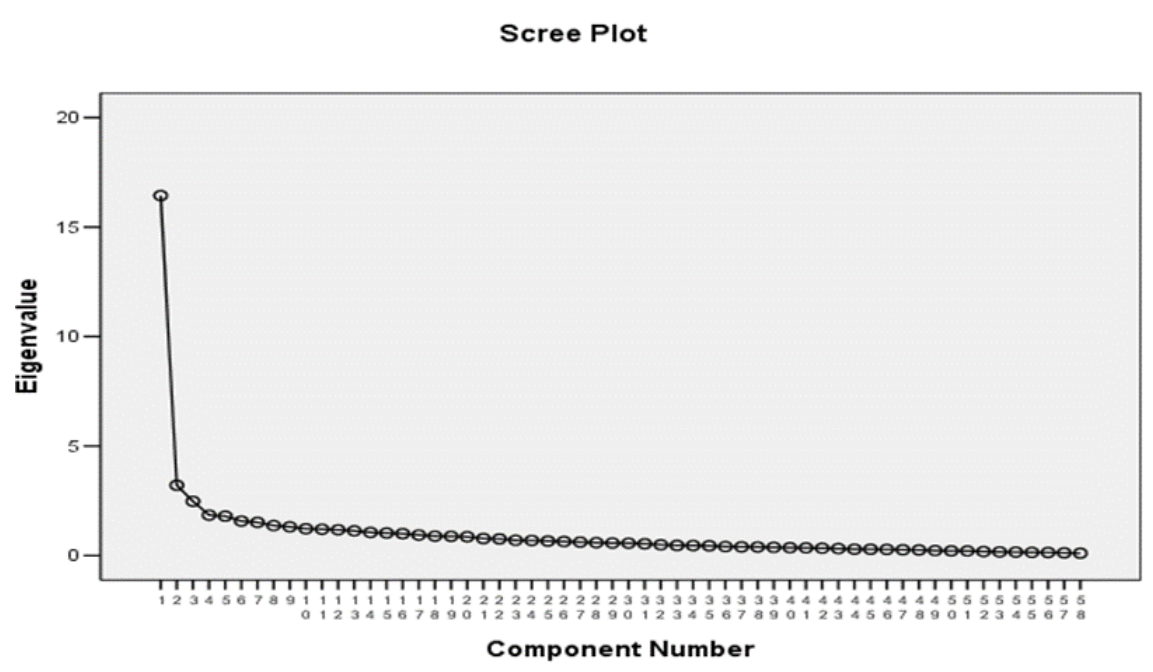

Figure 1. Factor Analysis Scree Plot Graph of the Scale 
Table 3. Rotated Factor Loads

\begin{tabular}{|c|c|c|c|}
\hline \multicolumn{4}{|c|}{ Factors } \\
\hline & 1 & 2 & 3 \\
\hline M22 & .813 & & \\
\hline M17 & .746 & & \\
\hline M2 & .727 & & \\
\hline M10 & .726 & & \\
\hline M18 & .681 & & \\
\hline M16 & .659 & & \\
\hline M15 & .627 & & \\
\hline M24 & .627 & & \\
\hline M3 & .572 & & \\
\hline M53 & .544 & & \\
\hline M9 & .480 & & \\
\hline M48 & .436 & & \\
\hline M60 & .361 & & \\
\hline M56 & & .748 & \\
\hline M57 & & .732 & \\
\hline M45 & & .705 & \\
\hline M38 & & .682 & \\
\hline M47 & & .647 & \\
\hline M61 & & .646 & \\
\hline M36 & & .624 & \\
\hline M37 & & .601 & \\
\hline M52 & & .559 & \\
\hline M40 & & & .816 \\
\hline M14 & & & .758 \\
\hline M27 & & & .479 \\
\hline
\end{tabular}

Method: Principal component analysis. Rotation Method: Varimax

When Table 3 is examined, it's seen that the first factor consists of items $(22,17,2,10,18,16,15,24,3,53,9$, 48, 60), the second factor consists of items $(56,57,45,38,47,61,36,37,52)$ and the third factor consists of items $(40,14,27)$.

For the construct validity of the scale confirmatory factor analysis was applied to the structure with 25 items and 3 factors. For confirmatory factor analysis, new data were collected by applying the re-designed scale (items ordered from 1 to 25$)$ to 266 participants.

Table 4. The first phase and the final phase of CFA goodness of fit results

\begin{tabular}{llll}
\hline \multicolumn{1}{c}{\begin{tabular}{c} 
Goodness of Fit \\
\multicolumn{1}{c}{ Index }
\end{tabular}} & \multicolumn{1}{c}{ Values } & \multicolumn{1}{c}{ Acceptable Fit } & \multicolumn{1}{c}{ Good Fit } \\
\hline Chi-Square $\left(\mathrm{X}^{2}\right)$ & 521,00 & & \\
Degrees of Freedom & 249 & & \\
Chi-Square/sd & 2,09 & $2 \leq \mathrm{X}^{2} / \mathrm{sd} \leq 5$ & $0 \leq \mathrm{X}^{2} / \mathrm{sd} \leq 2$ \\
RMSEA & 0,06 & $0,05 \leq \mathrm{RMSEA} \leq 0,10$ & $0 \leq \mathrm{RMSEA}<0,05$ \\
SRMR & 0,05 & $0,05 \leq \mathrm{SRMR} \leq 0,10$ & $0 \leq \mathrm{SRMR} \leq 0,05$ \\
GFI & 0,86 & $0,90 \leq \mathrm{GFI} \leq 0,95$ & $0,95 \leq \mathrm{GFI} \leq 1,00$ \\
AGFI & 0,83 & $0,85 \leq \mathrm{AGFI} \leq 0,90$ & $0,90 \leq \mathrm{AGFI} \leq 1,00$ \\
CFI & 0,97 & $0,95 \leq \mathrm{CFI} \leq 0,97$ & $0,97 \leq \mathrm{CFI} \leq 1,00$ \\
NNFI & 0,97 & $0,95 \leq \mathrm{NNFI} \leq 0,97$ & $0,97 \leq \mathrm{NNFI} \leq 1,00$ \\
NFI & 0,95 & $0,90 \leq \mathrm{NFI} \leq 0,95$ & $0,95 \leq \mathrm{NFI} \leq 1,00$ \\
\hline
\end{tabular}

According to $\overline{\mathrm{CFA}}$, in the first round, item 16 emerged as the most modification suggested item of the item pool of 3 factors and 25 items therefore it was omitted from the scale. At the second analysis, it's noted that a structure with 3 factors and 24 items was confirmed and all the goodness of fit indexes were in a reasonable level, (Table 4). 
Table 5. Standard loads, $\mathrm{R} 2$ values and $\mathrm{t}$ values as a result of CFA

\begin{tabular}{|c|c|c|c|}
\hline Items & Standard Loads & $\mathbf{R}^{2}$ & $t$ values \\
\hline \multicolumn{4}{|l|}{ Factor 1} \\
\hline M1 & 0,45 & 0,55 & 13,85 \\
\hline M2 & 0,49 & 0,51 & 13,11 \\
\hline M3 & 0,72 & 0,28 & 9,02 \\
\hline M4 & 0,55 & 0,45 & 12,10 \\
\hline M6 & 0,44 & 0,56 & 13,99 \\
\hline M7 & 0,37 & 0,63 & 15,24 \\
\hline M8 & 0,33 & 0,67 & 15,91 \\
\hline M9 & 0,39 & 0,61 & 14,99 \\
\hline M10 & 0,40 & 0,60 & 14,77 \\
\hline M11 & 0,58 & 0,42 & 11,56 \\
\hline M18 & 0,69 & 0,31 & 9,66 \\
\hline M20 & 0,69 & 0,31 & 9,58 \\
\hline M23 & 0,74 & 0,26 & 8,55 \\
\hline \multicolumn{4}{|l|}{ Factor 2} \\
\hline M13 & 0,63 & 0,35 & 10,36 \\
\hline M14 & 0,88 & 0,10 & 5,50 \\
\hline M15 & 0,48 & 0,52 & 13,10 \\
\hline M16 & 0,50 & 0,50 & 12,70 \\
\hline M17 & 0,50 & 0,50 & 12,60 \\
\hline M19 & 0,72 & 0,28 & 8,90 \\
\hline M21 & 0,48 & 0,52 & 13,01 \\
\hline M22 & 0,43 & 0,58 & 13,95 \\
\hline M24 & 0,55 & 0,46 & 11,87 \\
\hline \multicolumn{4}{|l|}{ Factor 3} \\
\hline M5 & 0,73 & 0,46 & 5,53 \\
\hline M12 & 0,83 & 0,12 & 4,97 \\
\hline
\end{tabular}

On table 5, it is seen that item 14 has the highest standard load values $(0,88), \mathrm{t}$ values $(5,50)$ and $\mathrm{R}^{2}$ values $(0,10)$; and item 8 has the lowest standard load values $(0,33)$, $t$ values $(15,91)$ and $R^{2}$ values $(0,67)$.

Lastly, factors were defined by looking at the alpha internal consistency values of the underlying dimensions. Besides that, items of the scale which was finalized with factor analysis were rearranged to determine which numbered item will be placed under which sub-dimension by renumbering them from 1 to 24 in an ascending order (Table 6). 
Table 6. Items comprising the sub dimensions and internal consistency values (alpha values) of the sub-dimensions

\begin{tabular}{|c|c|c|c|}
\hline & & $\begin{array}{l}\text { Number } \\
\text { of items }\end{array}$ & $\begin{array}{c}\text { Alpha } \\
\text { values of } \\
\text { sub-dime } \\
\text { nsions }\end{array}$ \\
\hline 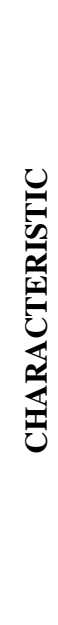 & $\begin{array}{l}\text { Item } 1 \text {. Resorts to illegal methods for victory. } \\
\text { Item 2. Blames the athletes in the event of failure. } \\
\text { Item 3. Does not make a statement to athletes in any subject } \\
\text { Item 4. Motivates the athletes by intimidating. } \\
\text { Item } 6 \text {. Uses his/her status for his/her own benefits. } \\
\text { Item 7. Acts irresponsibly. } \\
\text { Item } 8 \text {. Acts inconsistent most of the time. } \\
\text { Item 9. Tells lies. } \\
\text { Item 10. Demands that the athletes act illegally for victory. } \\
\text { Item } 11 \text {. Does not respect to personal choices. } \\
\text { Item } 18 \text {. Asks the athletes for things that they can't do. } \\
\text { Item 20. Resorts to violence in cases of his/her inability. } \\
\text { Item 23. Constantly argues with the referees during competition. }\end{array}$ & 13 & $\alpha=0.88$ \\
\hline 产 & $\begin{array}{l}\text { Item } 13 \text {. Tactically solves the game well. } \\
\text { Item } 14 \text {. Does not refrain to take risks in the game. } \\
\text { Item } 15 \text {. Cares about team work. } \\
\text { Item } 16 \text {. Does trainings within the plan. } \\
\text { Item } 17 \text {. Consistently follows the innovations in the field. } \\
\text { Item } 19 \text {. It is an advantage for us that he/she comes from within the field. } \\
\text { Item } 21 \text {. Meets my expectations. } \\
\text { Item } 22 \text {. Gives tactical instructions which I need during competition. } \\
\text { Item } 24 \text {. Improves my weaknesses during training. }\end{array}$ & 9 & $\alpha=0.86$ \\
\hline 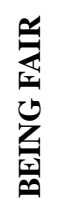 & $\begin{array}{l}\text { Item } 5 \text {. Gives more value to the athletes with high performance. } \\
\text { Item } 12 \text {. Treats the athletes of opposite sex more understandingly. }\end{array}$ & 2 & $\alpha=0.56$ \\
\hline
\end{tabular}

According to table 6, the first sub-dimension named as "Characteristic Features" consisted of 13 items (items 1, 2, 3, 4, $6,7,8,9,10,11,18,20$, and 23) with an internal consistency value of .88. The second sub-dimension entitled as "Knowledge and Skills Accumulation" consisted of 9 items (items 13, 14, 15, 16, 17, 19, 21, 22, and 24) and had an internal consistency value of .86. "Being Fair" as the third sub-dimension composed of items 5 and 12 with an internal consistency of.56. Items 1, 2, 3, 4, 6, 7, 8, 9, 10, 18, 20 and 23 were determined as reverse coded items. Turkish version of the scale can be seen in appendix part.

To measure the relationships between the sub-dimensions of the scale, Pearson Correlation Moment analysis was conducted and the results are given at Table 7.

Table 7. Relationships between the Sub-Dimensions of the Scale

\begin{tabular}{lccc}
\hline & $\begin{array}{c}\text { Characteristic } \\
\text { Features }\end{array}$ & $\begin{array}{c}\text { Knowledge and } \\
\text { Skills Accumulation }\end{array}$ & $\begin{array}{c}\text { Being } \\
\text { Fair }\end{array}$ \\
\hline Characteristic Features & 1 & $0,577^{* *}$ & $-0,399^{* *}$ \\
Knowledge and Skills Accumulation & & 1 & $-0,238^{* *}$ \\
Being Fair & & 1 \\
\hline
\end{tabular}

** 0.01 Significance Level

As it's shown on Table 7, Characteristic Features sub-dimension has a positive moderate relationship with Knowledge 
and Skills Accumulation sub-dimension $(r=0,57)$, and a negative moderate relationship with Being Fair $(r=-0,39)$ sub-dimension. It's also seen that there is a negative low level relationship between Knowledge and Skills Accumulation and Being Fair ( $\mathrm{r}=-0,23)$.

\section{Discussion}

In this study, a scale, which is going to be used in determination of perceived coach attitudes and behaviors by the athletes, was developed. In this part of the report, the findings gathered via statistical analysis procedures were discussed in the light of related literature.

For starters, measure of sampling adequacy test Kaiser-Meyer-Olkin (KMO) was conducted to decide the collected data's conformity for the factor analysis. It's seen by reviewing the literature that the closer the obtained value to 1 , the more suitable is the data to perform exploratory factor analysis (Akgül and Çevik ; 2005, Bayram; 2004, Şencan; 2005, Tavşanc1; 2006, Yarar et al.; 2016). When Table 1 is checked, it's noted that KMO measure of sampling adequacy value of the scale is 0.88 . It's observed that this value is excellent for KMO and it's suitable to conduct analysis on related data set. Also, Bartletts's Test of Sphericity was used to test the hypothesis of whether the correlation matrix is similar matrix or not (Akgül and Çevik, 2005). As a result of this test, the hypothesis was rejected at $\mathrm{P}<0,01$ level. This conclusion shows that the data set is fit for factor analysis by revealing the relationships among the items (Table 1).

After detecting the suitability of the gathered data for factor analysis, by examining the eigenvalues regarding the data at hand, it was found that the items which were processed at the final phase of the factor analysis were grouped under three factors that had eigenvalues greater than 1 . These three factors are explaining approximately $47.75 \%$ of the total variance (Table 2). In spite of the belief that the higher the variance ratio, stronger the factor structure according to the respective literature, variance ratios changing between $40 \%$ to $60 \%$ are accepted for the analysis in social sciences (Tavşanc1l, 2006). In light of the information, it can be said that the obtained variance is enough for the developed scale.

On Figure 1, the eigenvalues scree plot graph which has the eigenvalues on vertical axis and factors on horizontal axis can be seen. By examining the graphic it can be decided that suitable number of the factors on the vertical axis which is a scene of rapid declines with high momentum is three. It's also observed that contributions of additional factors subsequent to three are close to each other. On this basis, it is accepted that our measurement tool can be formed by three factors. As for factor loads cut-off point, it is decided as .40. Reasonableness of having .40 as factor loads cut-off point is supported by respective sources such as Akgül and Çevik, (2005), Hatcher, (1994) and Tavşanc1l (2006).

After testing the suitability of the data for factor analysis and possibility for the scale to be formed by three sub-dimensions, varimax rotation test was employed with the purpose of determining which items will be under which sub-dimensions. At the first step of this factor analysis of eight phases, items 7, 8, 11, 12, 13, 25, 26, 29, 30, 31, 32, 34, $35,39,42,50,59$ which were observed that the factor loads are below .40 and the values between two factor loads that were gathered at one item is under .10 were taken out of the analysis. At the second step, after varimax rotation method, items 4 and 5 were taken out because of the reason that the values between two factor loads gathered at these two items are below .10. After third rotation, item 33 was removed from the analysis as well for having value .10 between two factor loads gathered at this item. With fourth rotation, items $6,21,25,28,41,44$, and 45 were eliminated of the analysis for not conceptually having desired factor loads in accordance with the expectations of the researchers which means not fitting the theoretical structure. At fifth step, by looking at the Cronbach Alpha values of the remaining items, it was noted that the alpha value of the sub-dimension which contains items $23,43,54$ was below .50 and these items were removed from the analysis. After removing item 49 with the varimax rotation that was done again in sixth step, one of the sub-dimensions were left with only two items, therefore this sub-dimension was canceled and items 1 and 19 were taken out of the analysis too. As a result of the exploratory factor analysis which was done with varimax rotation that was performed for the last time, the scale was appeared to be a structure with 25 items and three factors (Table 3).

Confirmatory factor analysis (CFA) which is another validity method was performed on the structure with 25 items and 3 factors which were determined by exploratory factor analysis. CFA is a method to test whether a structure -which was already defined and its limits were already set- can be confirmed as a suitable model or not (Çokluk et al., 2010). When Table 4 is inspected, it was seen that CFI and NNFI of the model compatibility index values, belonging to the structure which contains 3 factors and 25 variables as a result of the first confirmatory factor analysis, were not within the acceptable compliance limits (Çokluk et al., 2010; Şimşek, 2007). There upon, modification suggestions that were given by the software (Lisrel) were investigated. Şimşek (2007) explained that removing the most repeated items in modification suggestions will lead to chi-square decreases and a stronger model structure will be raised. It was noted by the investigation made in this direction that the most modification suggestions were made for item 16 which was loaded at the third factor. This item was removed from the analysis and the process was repeated. In the wake of the performed analysis, it was observed that all the goodness of fit indexes reached to a reasonable level and the analysis was terminated. A structure of 3 factors and 24 items were confirmed in consequence of conducted CFA. Standard loads, R2 
and $t$ values regarding this structure were presented at Table 5 . When it's examined it's noticed that item 14's standard load value was the highest one (0.88), $\mathrm{t}$ values (5.50) and $\mathrm{R} 2$ values $(0.10)$; and item 8 's standard load value was the lowest one (0.33), t values (15.91) and R2 values (0.67).

It's indicated that $t$ value -revealing the relationship between observed variable and latent variable- will be significant at level 0.05 when it passes over 1.96 and at level 0.01 if it passes over 2.56 (Çokluk et al.; 2010 When the $t$ values between 24 items -which were formed with this analysis- and their latent variables inspected, it's noted that the lowest $t$ value belongs to item 12 (4.97) and it's over 2.56. While the standard load values show the correlation between each observed variable and related latent variable, R2 shows the strength of the relationship between the observed and latent variable (Çokluk et al., 2010; Şimşek, 2007). It can be said by checking that the standard loads and R2 values of 24 items which were subjected to analysis are in reasonable limits.

Afterwards, Cronbach's Alpha internal consistency test was employed to all the sub-dimensions and the scale which is composed of the items in total. Cronbach's Alpha internal consistency values of the sub-dimensions were delivered on Table 6. When the table is studied, the values were designated as for the first factor (Characteristic Features) $\alpha=0,88$, for the second factor (Knowledge and Skills Accumulation) $\alpha=0,86$ and for the third factor (Being Fair) $\alpha=0,56$. According to George and Mallery (2003) the Alpha values were explained as ".90 and above" is excellent, ".80 and above" is good," .70 and above" is acceptable, ".60 and above" is questionable, ".50 and above" is poor and finally "below .50" is unacceptable". Thus, when the alpha coefficients are examined, it can be said that they have good values. As for the cause of the third factor's Alpha coefficient being lower in comparison to the other factors, having low number of questions can be shown.

Correlation values of three sub-dimensions were calculated to interpret the construct validity of those sub-dimensions which emerged in the wake of factor analysis (Table 7). As a result of this calculation, it's seen that Characteristic Features sub-dimension has a positive moderate relationship with Knowledge and Skills Accumulation sub-dimension $(r=0,57)$, and a negative moderate relationship with Being Fair $(r=-0,39)$ sub-dimension. It's also noted that there is a negative low level relationship between Knowledge and Skills Accumulation and Being Fair ( $r=-0,23)$. According to the outcome of this analysis, unfair behaving tendencies of the Coaches will be low if they have high knowledge and skill level and a strong personality and character, therefore we can say that the relationship between sub-dimensions is as expected.

\section{Below are the psychometric features of the measurement tool.}

On the Characteristic Features dimension, what kind of impression coaches are leaving on athletes characteristics-as a result of reflection of some of the coach's characteristic features (blaming, self-seeking, threatening, violence, status, irresponsibility, inconsistency, miscommunication etc.) on the work life-is being measured.

On the Knowledge and Skills Accumulation dimension, how the coaches' backgrounds of knowledge and skills (technique, tactic, planning, training etc.) about the focused coaching area are being perceived by the athletes while the coaches are practicing their profession is being evaluated.

As for the Being Fair dimension, how the fairness level of the coaches' way of behaving to their athletes is being perceived and whether some of the specialties that the athletes have (gender, being the star athlete etc.) have an effect on the coaches' fair behaving pattern or not are being tested.

\section{Conclusion}

As a conclusion, it can be said that the developed "Perceived Coach Attitudes and Behaviors Scale" is a dependable measurement tool to determine how the behaviors of coaches in team and individual sports are being perceived by the athletes within the three designated sub-dimensions. In further studies, scale items and sub-dimensions can be broadened by adding new sub-dimensions and items covering such features as leadership, goal setting, planned working, discipline etc. and a more comprehensive scale can be developed in measuring coach attitudes and behaviors.

\section{References}

Akgül, A., \& Çevik, O. (2005). İstatistiksel Analiz Teknikleri, SPSS’te Işsletme Yönetimi Uygulamaları. Ankara: Emek Ofset.

Allport, G. W. (1935). Attitudes in Handbook of social psychology. Edited by C. Murchison, 798-844. Worcester, MA: Clark Univ. Press.

Bayram, N. (2004). Sosyal Bilimlerde SPSS ile Veri Analizi. Bursa: Ezgi Kitapevi.

Chelladurai, P. (1984). Discrepancy between preferences and perceptions of leadership behavior and satisfaction of athletes in varying sports. Journal of Sport Psychology, 6. https://doi.org/10.1123/jsp.6.1.27 
Çokluk, Ö., Şekercioğlu, G., \& Büyüköztürk, Ş. (2010). Sosyal Bilimler İ̧̧in Çok Değişkenli İstatistik. Ankara: Pagem Akademi

Dolaşır, T. S., \& Büyüköztürk, Ş. (2009). Antrenörlerin Mesleki Etik İlkeleri Nelerdir? Nasıl Ölçülür? Ölçek Geliştirme: Ölçeğin Geçerliliği ve Güvenirliği. Spormetre Beden Eğitimi ve Spor Bilimleri Dergisi, 7(4).

Gearity, B. T. (2012). Poor teaching by the coach: A phenomenological description from athletes' experience of poor coaching. Physical Education \& Sport Pedagogy, 17(1). https://doi.org/10.1080/17408989.2010.548061

George, D., \& Mallery, P. (2003). SPSS for Windows step by step: A simple guide and reference. 11.0 update (4th ed.). Boston: Allyn \& Bacon.

Gilbert, W. D., \& Trudel, P. (2004) Analysis of coaching science research published from 1970-2001.Research Quarterly for Exercise and Sport, 75. https://doi.org/10.1080/02701367.2004.10609172

Güven, Ö., \& Öncü, E. (2012). Antrenörlerin Etik Dışı Davranışları İle İlgili Sporcu Algısı Ölçeğinin geliştirilmesi. Spormetre Beden Eğitimi ve Spor Bilimleri Dergisi, 10(2).

Hatcher, L. (1994). A Step-by-Step Approach to Using The SAS (R) System for Factor Analysis and Structural Equation Modeling. Cary, NC: SAS Institute.

Karakoç, Ö., Yüksek, S., Aydın, A. D., Karakoç, B., Yetiş, Ü., \& Baydil B. (2011). Milli Takım Düzeyindeki Erkek Judocuların Kulüp Antrenörlerinde Gözlemledikleri Etik Dışı Davranışlar, Kastamonu Eğitim Dergisi, 19(1).

Kenow, L., \& Williams, J. M. (1999). Coach-athlete compatibility and athlete's perception of coaching behaviors. Journal of Sport Behavior, 22.

Şencan, H. (2005). Sosyal ve Davranışsal Ölçümlerde Güvenilirlik ve Geçerlilik. Seçkin Yayıncılık, Ankara.

Şimşek, Ö. F. (2007).Yapısal Eşitlik Modellemesine Girişs: Temel İlkeler ve LISREL Uygulamaları. Ankara: Ekinoks Yayınları.

Smith, R. E., Smoll, F. L., \& Curtis, B. (1979). Coach effectiveness training: A cognitive behavioral-approach to enhancing relationship skills in youth sport coaches. Journal of Sport Psychology, 1. https://doi.org/10.1123/jsp.1.1.59

Smith, R. E., Zane, N. W. S., Smoll, F. L., \& Coppel, D. B. (1983). Behavioral assessment in youth sports: Coaching behaviors and children's attitudes. Medicine and Science in Sport and Exercise, 15. https://doi.org/10.1249/00005768-198315030-00005

Tavşancıl, E. (2014). Tutumların Ölçülmesi ve SPSS ile Veri Analizi. Ankara: 3. Baskı, Nobel Yayınları, 2006.

Teatro, C. Coaching Efficacy and Stakeholders' Perceptions of Coaches: Relationships with National Coaching Standards, A Dissertation Presented in Partial Fulfillment of the Requirements for the Degree Doctor of Philosophy, Arızona State University.

Tharp, R. G., \& Gallimore, R. (1976). Basketballs John Wooden: What a coach can teach a teacher. Psychology Today, 9(8).

Yarar, H., Eroğlu, H., Uzum, H., \& Polat, E. (2016). Sporcu Kilo Düşme Yöntemleri ve Etkileri Ölçeği: Geçerlik ve güvenirlik çalışması. Journal of Human Sciences, 13(3). https://doi.org/10.14687/jhs.v13i3.4212

\section{Appendix}

\section{Turkish Version of Scale}

\section{Karakteristik Özellikler Boyutu}

Madde 1. Galibiyet için yasal olmayan yöntemlere başvurur.

Madde 2. Başarısızlık durumunda sporcuları suçlar.

Madde 3. Sporculara herhangi bir konuda açıklama yapmaz.

Madde 4. Sporcuları tehdit ederek motive eder.

Madde 6. Kendi çıkarları için statüsünü kullanır.

Madde 7. Sorumsuzca davranır.

Madde 8. Çoğu zaman tutarsız davranır.

Madde 9. Yalan söyler.

Madde 10. Galibiyet için sporculardan kural dışı hareket etmesini ister. 
Madde 11. Kişisel tercihlere saygı duymaz

Madde 18. Sporculardan yapamayacağı şeyler ister.

Madde 20. Yetersiz kaldığı durumlarda şiddete başvurur.

Madde 23. Müsabaka esnasında hakemlerle sürekli tartışır.

\section{Bilgi ve Beceri Birikimi}

Madde 13. Taktiksel olarak oyunu iyi çözer.

Madde 14. Oyun içerisinde risk almaktan kaçınmaz.

Madde 15. Takım çalışmasına önem verir.

Madde 16. Antrenmanları plan dahilinde yapar.

Madde 17. Alandaki yenilikleri sürekli takip eder.

Madde 19. Alan içinden gelmesi bizim için bir avantajdır.

Madde 21. Beklentilerimi karşılar.

Madde 22. Müsabaka esnasında ihtiyacım olan taktikleri verir.

Madde 24. Antrenman esnasında eksik yönlerimi geliştirir.

\section{Adaletli Olma}

Madde 5.Performansı yüksek olan sporculara daha fazla değer verir.

Madde 12. Karşı cinsten sporculara daha anlayışlı davranır.

\section{Copyrights}

Copyright for this article is retained by the author(s), with first publication rights granted to the journal.

This is an open-access article distributed under the terms and conditions of the Creative Commons Attribution license which permits unrestricted use, distribution, and reproduction in any medium, provided the original work is properly cited. 